\title{
Construction of site selected phage library and characterization of anti-V3 scFvs from Indian clade C HIV-1 infected patient
}

\author{
R Kumar ${ }^{*}$, R Andrabi, A Tiwari, P Somi Sankaran, N Wig, D Dutta, A Sankhyan, L Khan, S Sinha, K Luthra \\ From AIDS Vaccine 2012 \\ Boston, MA, USA. 9-12 September 2012
}

\section{Background}

Till date, few broadly neutralizing antibodies are generated against HIV-1 and they have limited breadth and potency against clade $\mathrm{C}$ viruses, which are predominant worldwide and in India. Here we have produced nine different human scFvs against the V3 region of HIV-1 envelope.

\section{Methods}

A V3 specific phage library was constructed from EBV transformed B cells of a clade C HIV-1 infected Indian patient, whose plasma exhibited good neutralization potential against a panel of viruses. Diversity of the constructed phage library was analysed by DNA fingerprinting of 10 randomly selected clones from the unselected library using BstN1 enzyme. One round of biopanning was done against HIV-1 consensus V3C and V3B peptides. scFvs were than characterised for their binding, specifity and expression profile. VH and VL genes of anti-V3 scFvs were sequenced for their preferential gene usage.

\section{Results}

DNA fingerprinting analysis of clones from unselected library showed that $90 \%$ of clones in the library were distinct. Thirty clones were randomly selected after biopanning. Nine clones showed binding in phage ELISA and exhibited a unique DNA fingerprint. Soluble expression of the selected scFvs was checked by SDS-PAGE and confirmed by Western blot. All the nine anti-V3 scFvs showed cross-reactivity against both the V3 peptides and did not bind to unrelated peptides. Distribution of $\mathrm{VH}$ gene segments of these anti-V3 scFvs were

All India Institute of Medical Sciences (AlIMS), New Delhi, India different, 56\% (5/9) of scFvs used VH4, thirty 33\% (3/9) VH5 and 11\% (1/9) showed VH3 gene usage. Among the light chains, IGKV1 and IGKV3 were most preferentially used gene segments. Further these scFvs displayed a stable binding to $\mathrm{V} 3$ peptides in different denaturing agents.

\section{Conclusion}

This is the first study to generate human anti-V3 scFvs against HIV-1 clade C. Further characterization of these scFvs for their neutralization potential and epitope mapping will provide useful information for immunogen design.

Published: 13 September 2012

doi:10.1186/1742-4690-9-S2-P291

Cite this article as: Kumar et al:: Construction of site selected phage library and characterization of anti-V3 scFvs from Indian clade C HIV-1 infected patient. Retrovirology 2012 9(Suppl 2):P291.

Submit your next manuscript to BioMed Central and take full advantage of:

- Convenient online submission

- Thorough peer review

- No space constraints or color figure charges

- Immediate publication on acceptance

- Inclusion in PubMed, CAS, Scopus and Google Scholar

- Research which is freely available for redistribution
(C) 2012 Kumar et al; licensee BioMed Central Ltd. This is an Open Access article distributed under the terms of the Creative Commons Attribution License (http://creativecommons.org/licenses/by/2.0), which permits unrestricted use, distribution, and reproduction in any medium, provided the original work is properly cited. 